\title{
THE EFFECT OF CASTRATION AND TESTOSTERONE REPLACEMENT ON SPERM MATURATION IN THE HAMSTER
}

\author{
G. M. LUBICZ-NAWROCKI* \\ Unit of Reproductive Biology, University of Liverpool, \\ Life Sciences Building, Liverpool L69 3BX
}

(Received 25th August 1972)

\begin{abstract}
Summary. Ligation of the distal corpus epididymidis and ductus deferens for 20 days resulted in low fertilizing ability of spermatozoa isolated in the cauda epididymidis of intact hamsters and castrated animals treated daily with $100 \mu \mathrm{g}$ testosterone. Following ligation of the ductuli efferentes and vasectomy in intact hamsters, however, new spermatozoa accumulated in the cauda epididymidis and fertilizing ability was maintained at the control level after 20 days. In the testosterone-treated castrated hamsters, the resulting fertilizing ability was dose-dependent: spermatozoa continued to migrate through the epididymis after twenty daily injections of either 12.5 or $100 \mu \mathrm{g}$ testosterone but developed fertilizing ability only after treatment with the higher dose of testosterone. The results show that circulating testosterone is important for sperm maturation in the hamster.
\end{abstract}

\section{INTRODUCTION}

Immature spermatozoa undergo a series of morphological and physiological changes after leaving the testis and acquire the ability to fertilize during their passage through the epididymis (Young, 1931; Bedford, 1966; Orgebin-Crist, 1967). These changes are complete by the time spermatozoa reach the distal cauda epididymidis where they are stored but spermatozoa lose their viability after prolonged storage (Hammond \& Asdell, 1926; Young, 1929; Tesh \& Glover, 1969; Lubicz-Nawrocki \& Glover, 1973).

The hormonal requirements for sperm maturation are not precisely known but it is likely that circulating testicular androgens are important since epididymal function is androgen-dependent (Risley, 1963; Martan, 1969). Recent observations show that castration prevents morphological changes in guinea-pig spermatozoa during epididymal transit (Blaquier, Cameo \& Burgos, 1972) and that circulating testosterone is important for the development of fertilizing ability in rabbits and rats (Orgebin-Crist, Dyson \& Davies, 1972). In order to evaluate the influence of circulating androgen on sperm maturation, the present

\footnotetext{
* Present address: Worcester Foundation for Experimental Biology, 222 Maple Avenue, Shrewsbury, Massachusetts 01545, U.S.A.
} 
experiments were undertaken to examine the effects of castration and testosterone replacement on the development of fertilizing ability in hamsters.

\section{MATERIALS AND METHODS}

Adult (10 weeks old) male and female hamsters, weighing 100 to $120 \mathrm{~g}$, were kept under a constant temperature $\left(26^{\circ} \mathrm{C}\right)$ and light $(15 \mathrm{hr})$ regimen and received a balanced diet (41B, Dixon \& Sons, Ltd, Ware, Herts) and water.

In order to test the effect of castration and testosterone replacement on sperm maturation, twenty-five males were divided into five equal groups and treated as follows: (1) bilateral isolation of the cauda epididymidis-the distal corpus epididymidis and proximal ductus deferens were ligated, using sterilized braided silk sutures (size 5/0, Ethicon, Ltd); (2) bilateral castration, isolation of the cauda epididymidis on both sides and daily treatment with $100 \mu \mathrm{g}$ testosterone; (3) bilateral vasectomy and bilateral ligation of the ductuli efferentes (efferentiectomy); (4) and (5) bilateral castration, bilateral vasectomy, bilateral efferentiectomy and daily treatment with 12.5 and $100 \mu \mathrm{g}$ testosterone, respectively. Castration and bilateral isolation of the cauda epididymidis were performed under sodium pentobarbitone anaesthesia through a scrotal approach (Lubicz-Nawrocki \& Glover, 1973) and the ductuli efferentes were ligated close to the testis to avoid disturbance to the arterial supply of the caput epididymidis. The animals in each group were killed after 20 days by cervical fracture and the fertilizing ability of spermatozoa pooled from the cauda epididymidis on both sides of each male was tested by the method of Lubicz-Nawrocki \& Glover (1973). The cauda epididymidis was macerated in $4 \mathrm{ml}$ sterile Hanks' solution and the material was filtered through sterile gauze; $0.2 \mathrm{ml}$ of the sperm suspension (filtrate) containing 10 to $15 \times 10^{6}$ spermatozoa was injected into each uterine horn of three oestrous females.

Eggs were flushed from the uterine tubes approximately $36 \mathrm{hr}$ after ovulation (Ward, 1946; Strauss, 1956) and whole mounts were prepared (Chang, 1952); the eggs were examined under a phase-contrast microscope and classified as fertilized by the presence of a spermatozoon in the vitellus of a cleaved egg. The fertilizing ability of each male was assessed in terms of 'fertilization rate' as the percentage of fertilized eggs recovered from three females.

The percentage of live spermatozoa in each suspension was estimated from smears stained with aqueous nigrosin-eosin (Lubicz-Nawrocki \& Glover, 1973) and the concentration of spermatozoa injected was determined from haemocytometer counts so that it was possible to estimate the number of live spermatozoa injected into each uterine horn. The number of spermatozoa in each cauda epididymidis 20 days after efferentiectomy and vasectomy (Groups 3, 4 and 5) was estimated from haemocytometer counts.

\section{RESULTS}

Table 1 shows that fertilizing ability was low 20 days after isolation of the cauda epididymidis in intact animals (Group 1) and in castrated animals treated daily with $100 \mu \mathrm{g}$ testosterone (Group 2). By contrast, when the whole epididymis 
Table 1. The effect of castration and treatment with testosterone on the fertilizing ability of hamster spermatozoa isolated for 20 days in the cauda epididymidis or

following isolation of the whole epididymis

\begin{tabular}{|c|c|c|c|c|c|}
\hline $\begin{array}{c}\text { Animal } \\
\text { group } \\
(n=5)\end{array}$ & Treatment & $\begin{array}{c}\text { Mean no. of live } \\
\text { sperm./uterine } \\
\text { hom } \times 10^{6}( \pm \text { S.E. })\end{array}$ & $\begin{array}{l}\text { Mean no. of eggs } \\
\text { recovered/3o+ } \\
\text { (with ranges) }\end{array}$ & $\begin{array}{c}\text { Mean no. of eggs } \\
\text { fertilized/3\%O }\end{array}$ & $\begin{array}{l}\text { Mean \% } \\
\text { fertilization rate* } \\
\quad( \pm \text { S.E. })\end{array}$ \\
\hline 1 & G.E. isolated & $2.5(1.3)$ & $39(31$ to 47$)$ & $10 \cdot 2$ & $23.0(12 \cdot 1)$ \\
\hline 2 & $\begin{array}{l}\text { Castration + C.E. } \\
\text { isolated }+100 \mu \mathrm{g} \\
\mathrm{T} / \text { day }\end{array}$ & $1.6(0.5)$ & 42 (32 to 50$)$ & $8 \cdot 4$ & $20.0(6.6)$ \\
\hline 3 & $\begin{array}{l}\text { Vasectomy + } \\
\text { efferentiectomy }\end{array}$ & $3.5(0.8)$ & $34(28$ to 44$)$ & $31 \cdot 0$ & $91 \cdot 1(6 \cdot 2)$ \\
\hline 4 & $\begin{array}{l}\text { Castration }+ \\
\text { vasectomy }+ \\
\text { efferentiectomy }+ \\
12.5 \mu \mathrm{g} \mathrm{T} / \text { day }\end{array}$ & $2 \cdot 1(0.8)$ & 36 (33 to 39$)$ & 0 & $0(0)$ \\
\hline 5 & $\begin{array}{l}\text { Castration }+ \\
\text { vasectomy }+ \\
\text { efferentiectomy }+ \\
100 \mu \mathrm{g} T / \text { day }\end{array}$ & $2 \cdot 6(0.5)$ & $42(30$ to 39$)$ & $40 \cdot 0$ & $95 \cdot 2(4 \cdot 7)$ \\
\hline
\end{tabular}

C.E. = cauda epididymidis; $\mathrm{T}=$ testosterone.

* Mean fertilization rate: average of five 'fertilization rates' obtained by estimating the fertilizing ability of each male.

was isolated from the rest of the reproductive system in intact animals (following efferentiectomy and vasectomy, Group 3), the sperm content of the cauda epididymidis increased after 20 days (Table 2) and fertilizing ability was maintained at the control level (Table 1).

It may be seen from Table 1 that the effect of testosterone on the development of the fertilizing ability in castrated hamsters was dose-dependent. Following castration, ligation of the ductuli efferentes and vasectomy, twenty daily consecutive injections of $12.5 \mu \mathrm{g}$ testosterone maintained the passage of spermatozoa through the epididymis and prevented sperm death but the spermatozoa were infertile. At the higher dose $(100 \mu \mathrm{g})$, however, fertilizing ability was high after 20 days (Table 1) and comparable to that found following vasectomy and efferentiectomy in intact animals (Group 3).

Table 2. The effect of castration and replacement with testosterone on the number of hamster spermatozoa in the cauda epididymidis 20 days after vasectomy and efferentiectomy

\begin{tabular}{|c|c|c|}
\hline $\begin{array}{l}\text { Animal } \\
\text { group } \\
(n=5)\end{array}$ & Treatment & $\begin{array}{c}\text { Mean no. of sperm. } \times 10^{6} \text { in right } \\
\text { and left cauda epididymidis } \\
( \pm S . E .)\end{array}$ \\
\hline $\begin{array}{l}\text { Untreated } \\
\text { controls }\end{array}$ & None & $245.4(9.9)$ \\
\hline 3 & Vasectomy +efferentiectomy & $410 \cdot 6(12 \cdot 2)$ \\
\hline 4 & $\begin{array}{l}\text { Castration }+ \text { vasectomy + efferentiectomy }+ \\
12.5 \mu \mathrm{g} / \text { day }\end{array}$ & $401 \cdot 2(8 \cdot 6)$ \\
\hline 5 & $\begin{array}{l}\text { Castration + vasectomy + efferentiectomy }+ \\
100 \mu \mathrm{g} \mathrm{T} / \text { day }\end{array}$ & $418.8(15 \cdot 6)$ \\
\hline
\end{tabular}

$\mathrm{T}=$ testosterone 
Table 1 shows that there was no relation between the mean number of live spermatozoa injected and fertilizing ability so that the low fertilizing ability of spermatozoa from animals in Groups 1 and 2 and infertility in Group 4 was not due to sperm death.

\section{DISCUSSION}

This study shows that the fertilizing ability of spermatozoa isolated in the cauda epididymidis is low after 20 days in intact hamsters and in castrated animals treated daily with $100 \mu \mathrm{g}$ testosterone, but remains high if new spermatozoa enter the cauda epididymidis. The resulting high fertilizing ability is a reflection of the survival of spermatozoa already present at the time of ligation and maturation and survival of the new spermatozoa, since most spermatozoa in the hamster caput and corpus epididymidis are infertile (Horan \& Bedford, 1972).

Maintenance of the fertilizing ability of mature hamster spermatozoa has been shown to be androgen-dependent (Lubicz-Nawrocki \& Glover, 1973) and exogenous testosterone prevents loss of fertilizing ability of mature spermatozoa in castrated rats and rabbits (Orgebin-Crist $e t a l ., 1972$ ). The present study shows that spermatozoa migrate through the epididymis in castrated hamsters receiving 12.5 or $100 \mu \mathrm{g}$ testosterone daily but that spermatozoa develop fertilizing ability only during treatment with the higher dose of testosterone. These results confirm recent observations showing that, in rats and rabbits, castration impairs sperm maturation but that exogenous testosterone maintains normal development of fertilizing ability (Orgebin-Crist et al., 1972).

It is still not clear to what extent the epididymal secretions contribute to sperm maturation and to what extent the process is simply due to inherent temporal changes within the spermatozoa. The many different testosteronedependent enzyme activities in the epididymis (Martan, 1969) suggest that circulating testosterone supports epididymal function which thereby maintains optimal conditions for the development of fertilizing ability. In rats injected with tritiated testosterone, the poor labelling of epididymal spermatozoa compared to epididymal tissue (Blaquier, 1971) supports the possibility of an indirect effect of testosterone on sperm maturation. However, testosterone is metabolized in the epididymis to $5 \alpha$-dihydrotestosterone and $3 \alpha$-androstanediol (Gloyna \& Wilson, 1969; Inano, Machino \& Tamaoki, 1969; Blaquier, 1971; Aafjes \& Vreeburg, 1972) so it is possible that small amounts of testosterone metabolites may enter the lumen of the duct and have a direct effect on the spermatozoa. Experiments are in progress to test this possibility.

\section{AGKNOWLEDGMENTS}

I am grateful to the Agricultural Research Council for financial support and to the Ford Foundation for laboratory facilities. Thanks are also due to $\mathrm{Dr}$ T. D. Glover for his help and advice during the preparation of the manuscript and to Mrs J. Kelly and Mrs V. Kelleher for typing assistance. 


\section{REFERENGES}

Aafjes, J. H. \& Vreeburg, J. Th. M. (1972) Distribution of $5 \alpha$-dihydrotestosterone in the epididymis of bull and boar, and its concentration in rat epididymis after ligation of efferent testicular ducts, castration and unilateral gonadectomy. 7 . Endocr. 53, 85.

BEDFORD, J. M. (1966) Development of the fertilizing ability of spermatozoa in the epididymis of the rabbit. 7. exp. Zool. 163, 319

BLAQuiER, J. A. (1971) Selective uptake and metabolism of androgens by rat epididymis. The presence of a cytoplasmic receptor. Biochem. biophys. Res. Commun. 45, 1076.

Blaquier, J. A., Cameo, M. S. \& Burgos, M. H. (1972) The role of androgens in the maturation of epididymal spermatozoa in the guinea pig. Endocrinology, 90, 839.

Chang, M. C. (1952) Fertilizability of rabbit ova and the effects of temperature in vitro on their subsequent fertilization and activation in vivo. 7. exp. Zool. 121, 351.

Gloyna, R. E. \& Wilson, J. D. (1969) A comparative study of the conversion of testosterone to $17 \beta$ hydroxy- $5 \alpha$-androstan-3-one (dihydrotestosterone) by prostate and epididymis. 7. clin. Endocr. Metab. 29, 970.

Hammond, J. \& Asdelz, S. A. (1926) The viability of the spermatozoa in the male and female reproductive tracts. Br. 7. exp. Biol. 4, 155.

Horan, A. H. \& BEDFord, J. M. (1972) Development of the fertilizing ability of spermatozoa in the epididymis of the Syrian hamster. F. Reprod. Fert. 30, 417.

Inano, H., Machino, A. \& TAMaOKI, B. I. (1969) In vitro metabolism of steroid hormones by cell free homogenates of epididymides of adult rats. Endocrinology, 84, 997

Lubicz-Nawrocki, C. M. \& Glover, T. D. (1973) The influence of the testis on the survival of spermatozoa in the epididymis of the golden hamster (Mesocricetus auratus). J. Reprod. Fert. 34, 315.

Martan, J. (1969) Epididymal histochemistry and physiology. Biol. Reprod. 1, 134.

ORGEBIN-CRIST, M. -C. (1967) Maturation of spermatozoa in the rabbit epididymis: fertilizing ability and embryonic mortality in does inseminated with epididymal spermatozoa. Annls Biol. anim. Biochim. Biophys. 7, 373.

Orgebin-Grist, M. -C., Dyson, A. L. M. B. \& Davies, J. (1972) Hormonal regulation of epididymal sperm maturation. In Fécondité et Sterilité du Mâle-Acquisitions Récentes, p. 227. Ed. G. Thibault. Masson et Gic, Paris.

Risley, P. L. (1963) Physiology of the male accessory organs. In Mechanisms Concerned with Conception, pp. 73-134. Ed. C. G. Hartman. Pergamon Press, Oxford.

Strauss, F. (1956) The time and place of fertilization of the golden hamster egg. F. Embryol. exp. Morph. 4,42 .

TEsh, J. M. \& Glover, T. D. (1969) Ageing of rabbit spermatozoa in the male tract and its effect on fertility. F. Reprod. Fert. 20, 287.

WARD, M. C. (1946) A study of the breeding cycle and the breeding of the golden hamster Cricetus auratus. Anat. Rec. 94, 139.

Young, W. C. (1929) A study of the function of the epididymis. II. The importance of an aging process in sperm for the length of the period during which fertilizing capacity is retained by sperm isolated in the epididymis of the guinea-pig. 7. Morph. 48, 475.

Young, W. C. (1931) A study of the function of the epididymis. III. Functional changes undergone by spermatozoa during their passage through the epididymis and vas deferens in the guinea-pig. F. exp. Biol. 8, 151. 